\title{
Freshwater Fish Cultivation
}

\author{
Khatunar Jahan ${ }^{1}$, Moushumi Janiam ${ }^{1}$
}

\section{${ }^{1}$ Department of Environmental Science, State University of Bangladesh, Bangladesh}

\begin{abstract}
This paper aimed to finding out about Freshwater Fish Cultivation. The research method used is descriptive method, namely the method of explaining a problem. In addition, the method used in this study is an explanatory method, namely a method that explains what, how are the results of the research itself far. There are several things that we must pay attention to when harvesting the results, including the tools used to collect the results, the methods used for harvesting the results and how to store the results. The tools used to collect fish are many ways including: hook, nets, Pecak, Anco, Bubu, Kere, and so on and it can also be done by drying the pond water as a whole, this is usually used for harvesting as a whole.
\end{abstract}

Keywords: Freshwater, Fish Cultivation, harvesting

\section{Introduction}

Fish are animals that live in water which is one of the many food ingredients needed by humans, fish are very useful for humans because they contain various substances that are needed by the human body such as: protein, vitamin A, vitamin B1 and vitamin B2 besides that is, when compared to other protein-producing sources such as meat, milk and eggs, the price of fish is relatively the cheapest.

Considering the importance of fish for humans, it is not surprising that humans try to obtain fish in sufficient quantities, among others, by searching for the source, namely the sea and there are those who choose it as well as possible which is commonly referred to as fisheries, fish maintenance is carried out directly in the sea. and some of the maintenance is carried out in ponds that are deliberately made by entrepreneurs,

The fish that are maintained in ponds are usually freshwater fish whose maintenance is entirely carried out in ponds that have been provided by these freshwater fisheries entrepreneurs.

\section{Fishery Business}

According to Korneyko \& Latkin (2015) freshwater fishery business in ponds is widely available in our society, especially in areas far from the sea, this business is carried out as a side or main business that can be cultivated in the yard of houses or empty land. The place for keeping this fish is named in various ways, some of which are called ponds, siwakan, ponds, cages and others.

\section{The Types that are Kept in Fresh Water}

Defined by Alber (2002) freshwater fish maintenance is generally rarely carried out only to maintain one type of fish, but in general it is a mixture of maintenance, this is because in the column there are actually various kinds of food for various types of fish, although we must 
pay attention to what types of fish are suitable as a staple pet and additional pet. Therefore, the mixing of the types of fish must be considered so that the fish are not harmed by each other. The fish that can be maintained in fresh water are as follows: (1) Mujaer / Tilapia mosambica (2) Tawes / Puntius Javanicus (3) Goldfish / Cyprinus carpio (4) Tambakan Fish / Helostoma temmincki (5) Patchouli fish / Osteochilus hasaelti (6) Milkfish / Chanos-chanos forsk (7) Siamese septic fish / Trichogaster pestoralis (8) Catfish / Clarias Bacrathus. (9) Fish Cork / Ophiocephalus striatus (10) Fish Cancera / Labeobarbus doronensis (11) And so on

\section{Old Maintenance}

The length of time to raise fish in fresh water with the highest yield takes 3-4 months, keeping fish in fresh water with an extended time of 5-6 months is actually very unprofitable this is because the extended time for raising fish is not a development The fish has a big body, but the food it eats is only used as energy material, which is used only for movement by the fish. Thus the costs we spend all the time being extended are just useless. Another advantage that we get if we raise fish in a period of 3-4 months, among others, in one year we can reap the results three times. It is different if we raise fish within 5-6 months. We will only be able to collect our pets' produce twice.

\section{Maintenance}

During the maintenance of fish in fresh water, what we have to do is, among other things, clean the water surface from pests and other animal disturbances.

\section{Method}

The research method used is descriptive method, namely the method of explaining a problem. In addition, the method used in this study is an explanatory method, namely a method that explains what, how are the results of the research itself. By conducting library visits and referencing several books in bookstores and by browsing on internet sites related to freshwater fish farming. The data collection technique used in this research is literature study. In this technique, it makes reference to books related to research and to browse the internet, so that there is a correlation between the title of the paper and the theory and implementation of the research itself. The analysis used in this research is descriptive analysis, namely the method of data analysis by describing the research results obtained.

\section{Result and Discussion}

\section{Making Freshwater Fish Ponds}

So that in raising freshwater fish to get satisfying results, we should choose a place and understand how to raise these freshwater fish. As for what we have to prepare for making the pool, among others (Steffens, 2006).

\section{Pick a Place}

The land we choose as a place for making freshwater fish ponds must be fertile soil or at least fertile soil and close to a water source, while soils consisting of rock or sandy soil are not good for keeping freshwater fish. The manufacture of fish container as a place for keeping fish can be divided into two groups, namely traditional and intensive (Meinhardt, 2012).

It should be noted that the surface of the pond must be tilted slightly towards the discharge gate so that the pond is easy to dry out when collecting the produce. There are two conditions for making a pool including: (1) The water inlet channel which is used is to enter 
the water into the pool (2) The drainage channel is usually made of two channels, one of which is made or installed on the surface of the pool according to the desired pool height which aims to or prevents the pool water from overflowing, while the second outlet channel is usually installed at the bottom of the pool embankment to be precise parallel to the bottom of the pool as for its use as a drain for pool water to drain when it is to be drained.

The types of freshwater fish ponds are as follows: (1) Triangle solid water ponds, which are usually built in places that have a water discharge of more than 300 liters of water per second. (2) Round pond, usually used as a freshwater fish hatchery. (3) Long ponds, long pools we usually encounter in irrigation areas are used as a place for maintenance.

\section{Freshwater Fish Nursery}

By Kraus \& Secor (2005) one of the factors that determines the success or failure of a fishraising business is depending on the good and bad seeds (seeds) that are sown. Therefore, before we do the nursery, we should make sure that the fish seeds that we are going to breed are healthy fish seeds, as for the way to determine fish seeds that are still healthy, one of them is by surprising the fish seeds, namely by clapping your hands on the water. after that we pay attention to the fish - the fish that are shocked and move nimbly, the fish seeds are still healthy and vice versa.

\section{Spread the Seeds}

The fish pond that we are going to spread with fish seeds must be dried for three days so that the bottom soil of the pond is completely dry and cracked, this is so that the wild fish seeds and germs in the pond we will make it a place for stocking fish seeds that we will keep as a whole dead.

The day before sowing the seeds, the pond is filled with water. At that time, it is better if the bottom of the pond is planted with chain algae (Hydrilla verticilata) which will be used as a place to live for algae - algae attached which is the main food of fish.

\section{Pisciculture}

The work that we have to do during the maintenance of the fish we raise is, among others, feeding fish, fertilizing ponds, and preventing or eradicating pests and disease. As we already know that in the pond there is already plankton - plankton as the main food for fish, besides that we can also provide additional food in the form of fine bran, twice a day and in sowing fine bran, try not to cover the surface of the pond with fine bran because it will be bad for the fish in the pond.

\section{Fertilize the Pond}

To increase the fertility of the pond, so that the results we expect to be satisfying the pond need to be fertilized, while the fertilizer we sprinkle into the pond can be compost (green manure) in the amount of about 1 ton for 10 are, this is so that the pond is not too dirty, and you can also make a cage for animals on the edge of the pool so that the waste can fall directly into the pool.

\section{Prevention / Eradication of Pests and Diseases}

According to Welte \& Terán, (2004) as with other businesses, fisheries business is not free from disturbances. Disturbances in freshwater fish farming include snakes, birds, crabs, wild fish, especially wild fish found in kolaam, monitor lizards, all of which are high-level pests and 
there are also diseases that often attack fish in general, parasites. Which include the following:

\section{Ichthyophitirius Multifiliis}

It is a parasite that causes spots on the body of the fish, especially on the fins, the prevention is by not spreading the pond with fish for three days.

\section{Mixobolus sp}

This parasite attacks a lot of fish body tissues causing swelling and this disease is highly contagious. Prevention is by separating fish that have been affected by this disease.

\section{Dactylogyrus}

This parasite usually attacks young fish, causing disease in the gulls and skin. The way to avoid this disease is by giving enough food to the young fish (Ŝimková et.al, 2004). Molecular phylogeny of congeneric monogenean parasites (Dactylogyrus): a case of intrahost speciation. Evolution, 58(5), 1001-1018.

\section{Ichtyoxenus Jelingha Usii Herklots}

This parasite is a poison that develops in the fish's body, but the fish itself is not disturbed. So that the fish themselves are not disturbed, and are not harmful to fish growth.

\section{Conclusion}

At the end of the maintenance period, the time we have been waiting for has arrived, namely collecting the results of the efforts we have been doing so far. There are several things that we must pay attention to when harvesting the results, including the tools used to collect the results, the methods used for harvesting the results and how to store the results. The tools used to collect fish are many ways including: hook, nets, nets, Pecak, Anco, Bubu, Kere, and so on and it can also be done by drying the pond water as a whole, this is usually used for harvesting as a whole. We can do freshwater fish maintenance as a side business and we can also make it the main business because the results of this effort are quite profitable besides the work or maintenance is not too complicated, the funds required are also not too large and the results can be felt immediately after 3-4 months we do this freshwater fish maintenance.

\section{References}

Alber, M. (2002). A conceptual model of estuarine freshwater inflow management. Estuaries, 25(6), 1246-1261.

Korneyko, O. V., \& Latkin, A. P. (2015). Integration of fishery enterprises in the Primorsky region: economic rationales and ways of their realization. Mediterranean Journal of Social Sciences, 6(5 S3), 118.

Kraus, R. T., \& Secor, D. H. (2005). Application of the nursery-role hypothesis to an estuarine fish. Marine Ecology Progress Series, 291, 301-305.

Lazard, J. (2009). La pisciculture des tilapias.

Meinhardt, H. I. (2012). Cooperative decision making in common pool situations (Vol. 517). Springer Science \& Business Media 
Molnár, K., Marton, S., Eszterbauer, E., \& Székely, C. (2006). Comparative morphological and molecular studies on Myxobolus spp. infecting chub from the River Danube, Hungary, and description of $M$. muellericus sp. n. Diseases of Aquatic Organisms, 73(1), 49-61.

Ŝlmková, A., Morand, S., Jobet, E., Gelnar, M., \& Verneau, O. (2004). Molecular phylogeny of congeneric monogenean parasites (Dactylogyrus): a case of intrahost speciation. Evolution, 58(5), 1001-1018.

Steffens, W. (2006). Freshwater fish-wholesome foodstuffs. Bulgarian Journal of Agricultural Science, 12(2), 320.

Welte, V. R., \& Terán, M. V. (2004). Emergency prevention system (empres) for transboundary animal and plant pests and diseases. the empres-livestock: an fao initiative. Annals of the New York Academy of Sciences, 1026(1), 19-31. 